\title{
d

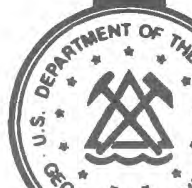 \\ U.S. GEOLOGICAL SURVEY GROUND-WATER STUDIES IN NEW HAMPSHIRE
}

\section{GROUND-WATER ISSUES}

Ground-water is the primary source of supply for about 57 percent of the 1.1 million people that live in New Hampshire. Of the 27 municipalities with a population greater than 7,000, 9 are served by water systems that use ground water, 11 by systems that use surface water, and 7 by systems that use combined sources. Total ground-water use in New Hampshire is about 84 million gallons per day. Almost 70 percent of this total is used in the southern part of the State in Merrimack, Hillsborough, Rockingham, and Sullivan Counties. Of the total ground water withdrawn, about 40 percent is used by industry, and the remainder is used for domestic and commercial purposes. The major issues related to ground water in New Hampshire are:

- Availability and

- Contamination from landfills and hazardous waste sites.

\section{U.S. GEOLOGICAL SURVEY PROGRAMS}

The U.S. Geological Survey (USGS), established in 1879 , is the principal source of scientific and technical expertise in the earth sciences within the Federal government. USGS activities include research and services in the fields of geology, hydrology, and cartography. The mission of the Water Resources Division of the USGS is to develop and disseminate scientific information on the Nation's water resources. The activities of the Water Resources Division in New Hampshire are conducted by scientists, technicans, and support staff in offices in Bow.

Hydrologic-data stations are maintained at selected locations throughout New Hampshire to record stream discharge and stage, reservoir and lake storage, ground-water levels, well and spring discharge, and the quality of surface and ground water. Water-resources data are stored in the USGS National Water Data Storage and Retrieval System data base. These data are used by water planners and others involved in decisions that affect New Hampshire's water resources.

During 1987, the USGS, in cooperation with Federal, State, and local agencies, maintained a network of about 270 observation wells in New Hampshire to monitor fluctuations of water levels. Water-level measurements from wells are used to monitor ground-water trends; however, they need to be integrated with other observations and ground-water investigations to be most relevant and useful.

The USGS has conducted more than 35 hydrologic investigations in New Hampshire since 1960. During fiscal year 1987, the USGS was involved in 12 cooperative agreements with State and Federal agencies of which 7 involved ground-water investigations. These investigations will provide information needed to answer hydrologic questions that are specific to the State's principal ground water issues. Also, some of these investigations will provide information needed on statewide, multistate, and nationwide hydrologic problems. Three examples of ground water studies by the USGS that address specific ground-water issues in New Hampshire are discussed in the following sections.

\section{Detailed Statewide Ground-Water Mapping Program}

Recent increases in population and industry have increased demands on ground water and detailed information to assist in the management of the ground-water resource is needed. To meet this need, the USGS embarked on a 10-year cooperative program in 1983 with the New Hampshire Department of Environmental Services to provide detailed maps of sand-and-gravel aquifers throughout the State. Maps that show aquifer boundaries, watertable altitudes, general directions of ground-water flow, saturated thickness, and aquifer transmissivity are being compiled at a scale of 1 inch equals 2,000 feet. The study also provides data on the background water quality in sand and gravel aquifers throughout the State. In each of the 14 study areas that will be examined by 1993 , computer-modeling techniques will provide estimates of ground-water yields for representative aquifers. In addition, the contributing recharge areas for selected wells are

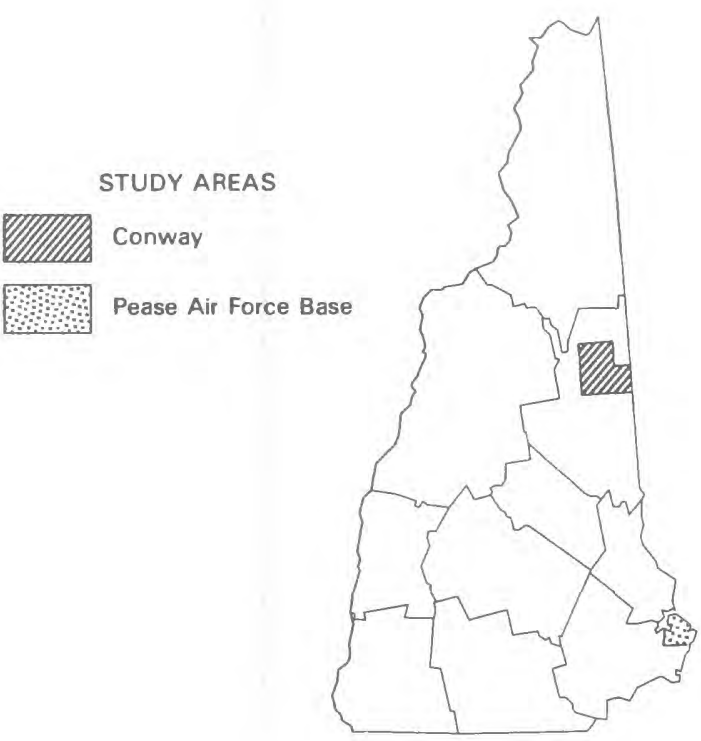


being delineated. As of 1988 , three of the study areas are completed and six more are in progress.

\section{Ground Water Contamination, Pease Air Force Base}

Trichloroethylene (TCE), in concentrations that could be hazardous to health, was found in ground water from a sandand-gravel aquifer that underlies Pease Air Force Base. The highest concentrations of TCE were found during 1977 and 1978 in the area of the most productive well in the aquifer. TCE was used for degreasing machinery at the base from 1955 until about 1973. In June 1977, the USGS, in cooperation with the U.S. Air Force (USAF), began to evaluate the water resources and extent of ground-water contamination at Pease Air Force Base. The USGS study proceeded in two phases. The first phase involved aquifer tests and sampling of water from the principal supply wells for the presence of volatile organic compounds. The second phase included drilling of test holes, periodic waterlevel measurements, and more extensive chemical sampling. The study results were used to delineate the area of contamination and will be used by the USAF in water-management strategies to alleviate the contamination at principal supply wells.

\section{Effects of Waste Disposal on Ground Water, Near Conway}

The sand-and-gravel aquifer along the Saco River near Conway is an important source of water for several towns in the region. Because of its proximity to recreation areas in the White Mountains, Conway has experienced rapid population growth in recent years. This growth has led to concerns about the effects of increased septic-waste disposal on ground-water quality. In 1984, the USGS, in cooperation with the State of New Hampshire and the town of Conway, began a detailed investigation to determine the effects of septic-waste disposal on ground-water quality. The project involved the use of surface geophysics, test drilling, water-quality sampling, and computer modeling of ground-water flow. Results of the study include aquifer maps that show directions of ground-water flow, saturated thickness, water quality, and hydraulic conductivity. The computer model was used to estimate the location of recharge areas for municipal wells in the aquifer under present and proposed pumping conditions. The State and the town of Conway have used data from the study to guide development of water supply and to initiate construction of a sewage-collection and treatment facility.

\section{GROUND-WATER MANAGEMENT}

The principal State agencies responsible for ground-water management in New Hampshire are the Department of Environmental Services, Water Resource Division, Water Supply and Pollution Control Division, and Waste Management Division; and the New Hampshire Department of Public Health Services, Environmental Health Risk Assessment Unit. The Water Resource Division collects water-use data, licenses well drillers, maintains well-completion data, and assesses groundwater availability. The Water Supply and Pollution Control Division has responsibility for water quality and related watersupply aspects of ground-water protection. The Waste Management Division is responsible for permitting solid- and hazardouswaste disposal sites, and the Environmental Health Risk
Assessment Unit is responsible for assessing health risks related to ground-water use. The New Hampshire Office of State Planning establishes rules governing local water-resource management and protection planning. All of these agencies use ground-water data and the results of ground-water studies provided by the USGS. The following Federal, State, and local agencies have entered into interagency or cooperative costsharing agreements with the USGS to conduct ground-water investigations in New Hampshire:

\section{Cornell University}

Institute of Ecosystem Studies, New York Botanical Garden

Nashua Regional Planning Commission

New Hampshire Department of Environmental Services

Water Resources Division

Water Supply and Pollution Control Division

New Hampshire Department of Resources and Economic Development Town of Conway

U.S. Air Force

U.S. Army Corps of Engineers

U.S. Environmental Protection Agency

U.S. Forest Service

\section{SELECTED REFERENCES}

Bradley, Edward, 1982, Trichloroethylene in the ground-water supply of Pease Air Force Base, Portsmouth, New Hampshire: U.S. Geological Survey Water-Resources Investigations Open-File Report 80-557, $22 \mathrm{p}$

Johnson, C.D., Tepper, D.H., and Morrissey, D.J., 1987, Geohydrologic and surface-water data for the Saco River Valley glacial aquifer from Bartlett, New Hampshire, to Fryeburg, Maine-October 1983 through January 1986: U.S. Geological Survey Open-File Report 87-44, 80 p.

Morrissey, D.J., and Regan, J.M., 1987, New Hampshire ground-water quality: U.S. Geological Survey Open-File Report 87-0739, 8 p.

Toppin, K.W., 1987, Hydrogeology of stratified-drift aquifers and water quality in the Nashua Regional Planning Comission area, southcentral New Hampshire: U.S. Geological Survey Water-Resources Investigations Report 86-4358, $45 \mathrm{p}$.

U.S. Geological Survey, 1984, National Water Sumary 1983Hydrologic events and issues: U.S. Geological Survey Water-Supply Paper 2250, 243.

1985, National water summary 1984-Hydrologic events, selected water-quality trends, and ground-water resources: U.S. Geological Survey Water-Supply Paper 2275, 467 p.

Wiltshire, D.A., Lyford, F.P., and Cohen, A.J., 1986, Bibliography on ground water in glacial-aquifer systems in the northeastern United States: U.S. Geological Survey Circular 972, 26 p.

Information on technical reports and data related to ground water in New Hampshire can be obtained from:

Office Chief

U.S. Geological Survey

Water Resources Division

RFD 12, 525 Clinton Street

Bow, New Hampshire 03301

Director

New Hampshire Water Resources Research Institute

University of New Hampshire

Durham, New Hampshire 03824

Open-File Report 88-142

Daniel J. Morrissey, 1988 